\title{
READING OF GROUND-PENETRATING RADAR (GPR) IMAGES OF PREHISTORIC FLINT MINE; CASE STUDY FROM KRZEMIONKI OPATOWSKIE ARCHAEOLOGICAL SITE IN CENTRAL POLAND
}

\author{
Fabian Welc ${ }^{1}$, Radosław Mieszkowski ${ }^{2}$, Lawrence B. Conyers ${ }^{3}$, Janusz Budziszewski ${ }^{1}$, Artur Jedynak ${ }^{4}$ \\ ${ }^{1}$ Institute of Archaeology, Cardinal Stefan Wyszyński University in Warsaw, Poland, \\ e-mails:f.welc@uksw.edu.pl, j.budziszewski@uksw.edu.pl \\ ${ }^{2}$ Faculty of Geology, University of Warsaw, Poland, e-mail: .mieszkowski@uw.edu.pl \\ 3 Department of Anthropology, University of Denver, USA, e-mail: lconyers@du.edu \\ ${ }^{4}$ Archaeological Museum and Reserve „Krzemionki”, Poland, e-mail: artur.archeo@krzemionki.info
}

\begin{abstract}
Geophysical surveys conducted in order to map tunnels and vertical shafts at the Neolithic chert mining field Krzemionki used a ground-penetrating radar (GPR) to test hypotheses regarding orientation, depth and subsurface complexity of these voids. Using two-dimensional reflection profiles the vertical shafts, now mostly filled with lithic debris, were easily visible. Amplitude mapping visualized debris at shaft margins as well as a collapsed material inside the voids. Some shallower horizontal tunnels were also visible as sub-horizontal planar reflections generated from both ceiling and floors of these void spaces. Extension of these interpretations to un-mapped areas of the ancient mining district and complexity of these prehistoric mining features could be examined to determine excavation intensity and exploitation techniques used during the Neolithic.
\end{abstract}

Key words: ground-penetrating radar, prehistoric flint mines, Krzemionki Opatowskie, Poland.

Manuscript received 9 September 2016, accepted 8 November 2016

\section{INTRODUCTION}

The ground-penetrating radar (GPR) method is still infrequently used in examination of prehistoric mining fields, caves and rock shelters. This is because these structures have usually a complex stratigraphy and spatial architecture as well as void spaces, which are difficult to interpretation in three-dimensional models (Collins et al., 1994; Chamberlain, 2000; Beres et al., 2001; El-Quady et al., 2005; Leucci and De Giorgi, 2005; Zhao et al., 2015; Conyers, 2016).

Compared to other archaeological remains, prehistoric flint mines have usually an extremely complex underground structure and they are therefore very hard to detect by geophysical methods including GPR. Most problems are connected with interpretation of geophysical data. Despite these difficulties, some GPR surveys of prehistoric mining shafts and tunnels have been occasionally undertaken (see Leopold and Völkel, 2005; Galiberti et al., 2011 Koch et al., 2013).

Some of us began survey using GPR at extensive prehistoric flint mine at Krzemionki Opatowskie in 2014, in order to test hypotheses concerning a depth of mine shafts preserved at this archaeological site and to recognize them in radar reflection profiles, focused on their types and geometry (also with correlation and comparison to other similar struc- tures). Another aim was to determine the most effective procedures of GPR data processing and interpretation, which could be used in future survey of prehistoric mining fields in Poland, much of which have been still un-explored by archaeologists.

One of the first GPR survey was performed in the mining field at Krzemionki Opatowskie in 1983, during which a GSSI radar system (SIR-3) was used. In this initial survey unprocessed reflection profiles were capable of recognizing and distinguishing particular types of mining features and determining general spatial pattern of shafts and exploitation galleries. These studies proved a usefulness of the GPR method in non-invasive mapping of such deep voids and distinguishing difference between a system of exploitation shafts and more horizontal exploitation galleries (Borkowski, 1990a, 1990b, 2000). Equally interesting GPR results were obtained in the prehistoric (Neolithic and Early Bronze Age) mining field at Borownia near Krzemionki Opatowskie (central Poland), which has not been so far examined by archaeologists. Field data were collected using Mala Geoscience ground-penetrating radar. This research allowed pre-identifying an underground structure of the Borownia mining field. Processed reflection profiles revealed three distinct concentration zones of GPR anomalies. The central zone appeared 


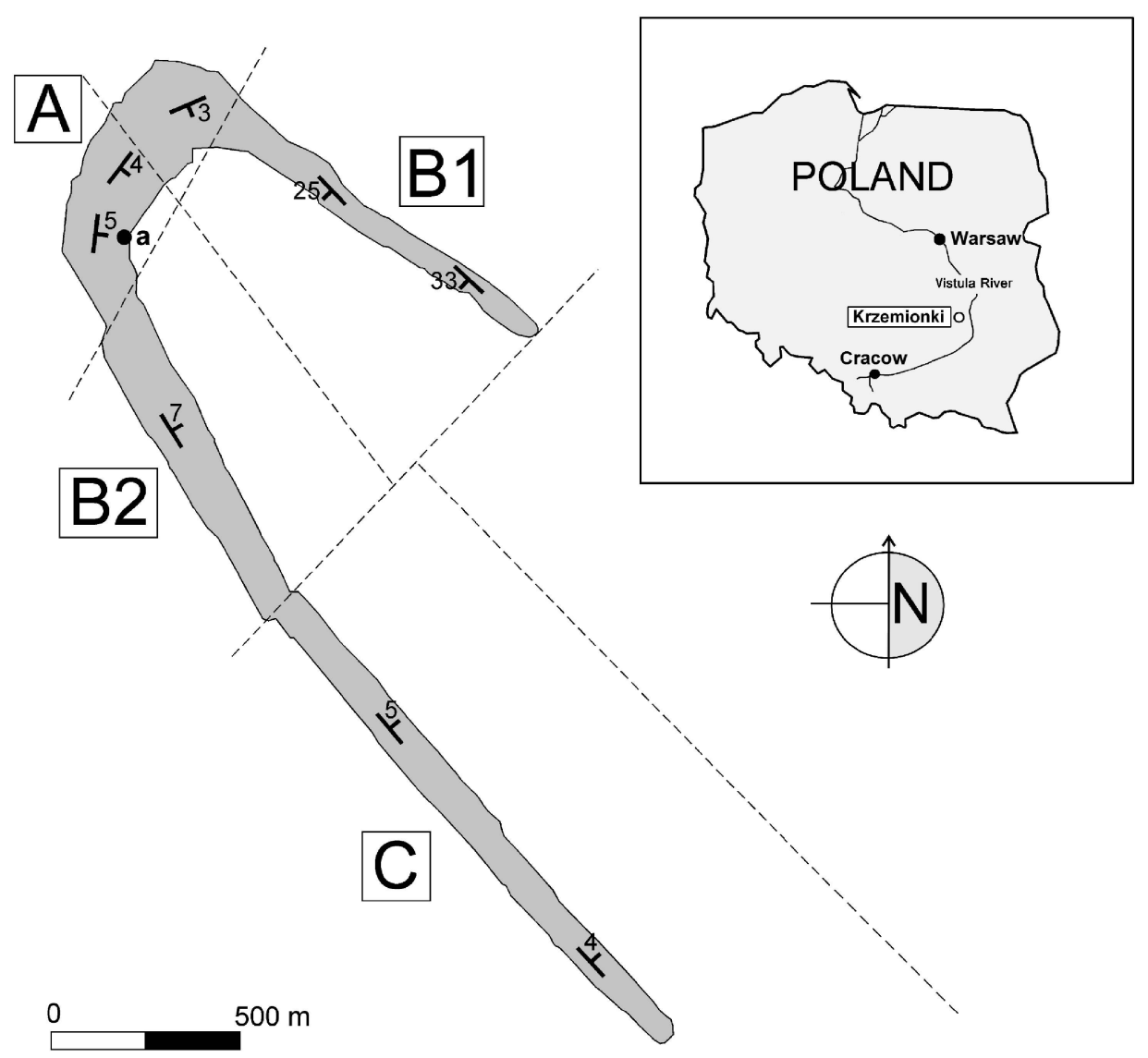

Fig. 1. Location and structure of the Neolithic mining field at Krzemionki with bedding strike and dip. The fault system (dashed line) separates the site into four segments referred to as A, B1-B2 and C. The area searched by GPR is marked as 'a' (after Borkowski, 1995a, modified and supplemented).

to be a fragment of a prehistoric mining field and was confirmed by surface archeological surveys, the other two have not been identified yet. Based only on results of this GPR survey it is not possible to determine a chronology of prehistoric mining activities in particular zones of the mining field at Borownia (Boubaki et al., 2012; Welc et al., 2013, Mieszkowski et al., 2014).

\section{SIGNIFICANCE AND STRUCTURE OF THE NEOLITHIC MINING FIELD AT KRZEMIONKI OPATOWSKIE}

The vast archaeological site at Krzemionki Opatowskie belongs to a unique system of prehistorical mines of the Upper Jurassic flint in the north-eastern Permian-Mesozoic margin of the Holy Cross Mountains in central Poland, which is presently an object on a tentative list to become a World Heritage UNESCO site (Fig 1). The complex has functioned from the Neolithic until the Early Bronze Age (mid- $4^{\text {th }}$ millennium $\mathrm{BC}$ to the mid- $2^{\text {nd }}$ millennium $\mathrm{BC}$ ). Original mines at Krzemionki were established likely during activity of the Funnel Beaker Culture (FBC) and Globular Amphora Culture (GAC) (Borkowski, 1995b; Bąbel, 2008). At present, the Krzemionki site contains about 4000 prehistoric mines, occurring within a belt, $4.5 \mathrm{~km}$ long and 20-200 m wide (Babel, 1986, 2015). They are visible on the surface as de- pressions (which are vertical shafts, now filled with debris), surrounded by dumps of reworked material and dug during excavation of shafts, pits and niche-gallery mines. A general shape of the field follows an outcrop of bedding of prehistorically exploited striped flint and is found at a depth where it could have been exploited. The area of exploitation has a parabolic shape, mimicking the structure of a local syncline, transversely cut by numerous faults that subdivide the mining field into three main parts indicated as segments A, B and C (Borkowski and Michniak, 1992; Bor- kowski, 1995a, b) (Fig. 1).

Archaeological works at Krzemionki have allowed distinguishing four main types of prehistorical mining objects at the site (Fig. 2):

1. Shallow pit mines that are the simplest of all features dug in subsurface rock debris, reaching $3.5 \mathrm{~m}$ in depth, with a shaft not exceeding $4 \mathrm{~m}$ in diameter.

2. Niche-gallery mines, which have exploitation niche running from the shaft into a rock massif at about $2 \mathrm{~m}$ and their depth does not exceed $4.5 \mathrm{~m}$.

3. Pillar-chamber mines, reaching depth $6 \mathrm{~m}$. Mines of this type are composed of a shaft and mining corridors leading to a depth of about $7 \mathrm{~m}$ in the rock massif. Pillars prevented a ceiling collapse.

4. Chamber mines, which are composed of a deep shaft reaching a depth $9 \mathrm{~m}$ and a vast underground excavation 


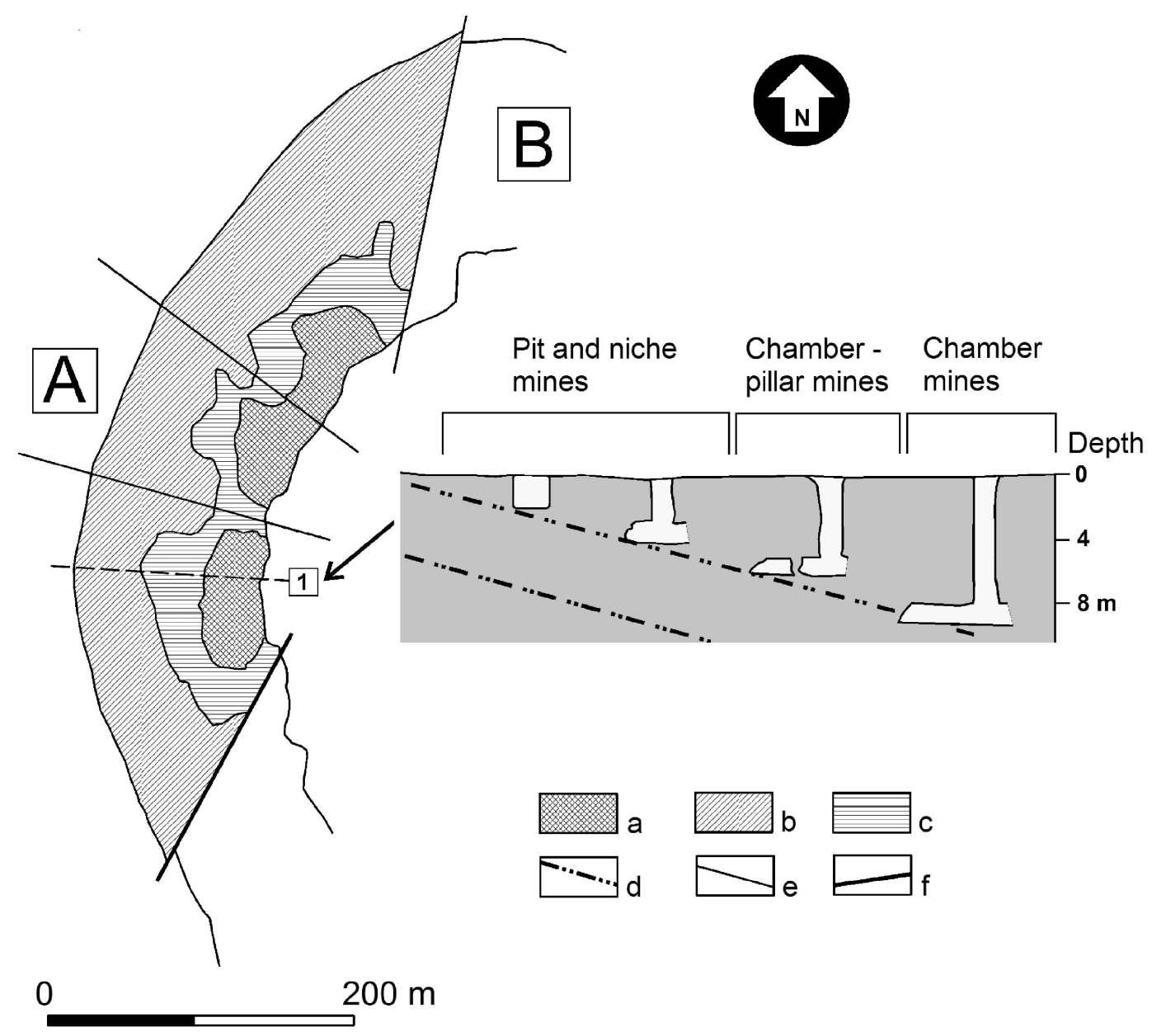

Fig. 2. Structure of the segment A at Krzemionki Opatowskie and scheme of flint exploitation. $a$-zone of pit and niche mines, $b$ - zone of chamber-pillar mines, c - zone of chamber mines, d - flint layers, e - transverse fractures, $\mathrm{f}$ - faults (after Borkowski and Michniak, 1992, modified by F. Welc).

complex, which is composed of a system of chambers and corridors reaching $15 \mathrm{~m}$ in a limestone massif (Borkowski and Michniak, 1992; Borkowski, 1995a).

Flint-bearing horizons in the segment A (Fig. 2) dip towards the syncline centre at an angle of about $5^{\circ}$. The middle belt, where the flint beds are deeper, contains niche mines, with distances between particular vertical shafts not exceeding $8 \mathrm{~m}$. In both pit and niche mines, only the upper flint layer was exploited. Deeper mines with distinct dumps around the post-shaft depressions were recognized in a central part of the field. There are shafts at distance of about $10 \mathrm{~m}$ from each other. These deeper mines are of a chamber-pillar type. The deepest and most external belt in the segment A comprises chamber mines reaching $9 \mathrm{~m}$ in depth. The flint-bearing layers dip at about $5^{\circ}$ to the northeast, which determines a specific pattern of the mining structures from the shallowest pit mines near the surface to the deepest, chamber mines, where they reach the furthest technical range of exploitation.

\section{GPR DATA COLLECTION AND PROCESSING}

A depth of radar waves in a ground depends both on nominal frequency of transmitting antenna and electrical resistivity of the medium (Conyers, 2013). Lower frequency of the antennas can result in deeper energy penetration, but with much lower resolution in the same time. In extremely unfavourable cases, for instance in low-resistivity soils or rocks rich in conductive clays, energy attenuation occurs at a shallow depth, no matter what is a frequency of the propagating energy (see Conyers and Goodman, 2007; Conyers, 2013, 2016).

During a geophysical survey conducted at the Krzemionki mining field, the Mala GPR radar system was used with 250, 500 and $100 \mathrm{MHz}$ antennas (Fig. 5). All reflection profiles were processes using ReflexW (www.sandmeiergeo.de), GPR Process and GPR slices software (www.gprarchaeology.com). For comparison, the same record parameters of reflected waves were used, as well as signal compilation to enhance small amplitudes of usable reflexes and restricting a possibility of registering random and low-amplitude noises. Registration of survey lines was conducted in a time window depending on a type of the applied antenna.

During data processing, several procedures were applied for better imaging in relation to the background, i.e. noise. The applied procedures can be subdivided into two groups:

1. Operations on a single georadar trace (1D filter), conducted individually on each line: running average, DC shift, subtract-mean, gain, AEG gain, manual gain, moved start time and band pass frequency. 

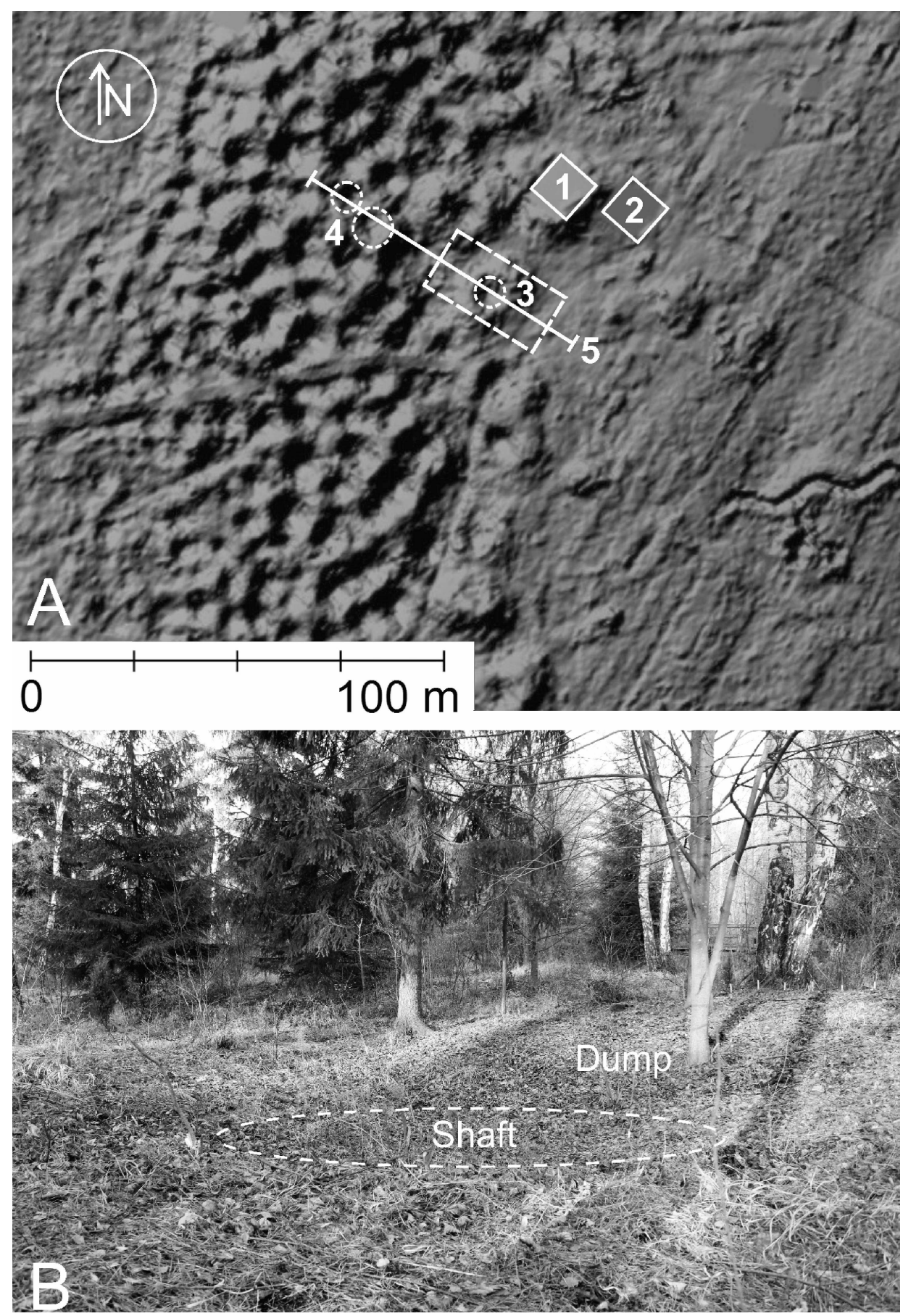

Fig. 3. Fragment of the segment mining field A at Krzemionki Opatowskie on LIDAR image. 1,2 - tourist pavilions, 3 - location of the shaft 612 and area of GPR survey, 4 - two mines adjacent to the shaft 612 from the west, 5 - location of the long correlation GPR profile across all three objects; for other explanations see text.

2. Operations on a group of traces (2D filter): background removal, average xy filter, complex trace analysis, deconvolution, filtration, migration.

The last advanced processing procedure of selected groups of GPR reflection profiles resulted in their compilation in quasi $3 \mathrm{D}$ block diagrams using $3 \mathrm{D}$ data interpretation modulus of Reflex View (on application of GPR in archaeology see more in: Vaughan, 1986; Imai et al., 1987; Goodman 1994; Conyers and Goodman, 2007; Conyers 2013).

\section{LOCATION AND GEOLOGICAL STRUCTURE OF THE SHAFT 612}

The study area is located in a southern part of the segment A of the Krzemionki mining field (Fig. 1A). This area of carbonate rock is excellent for GPR studies as this medium is electrically resistive and therefore does not attenuate propagating electromagnetic energy. Enough energy is therefore transmitted to depths where tunnel void spaces reflect energy 

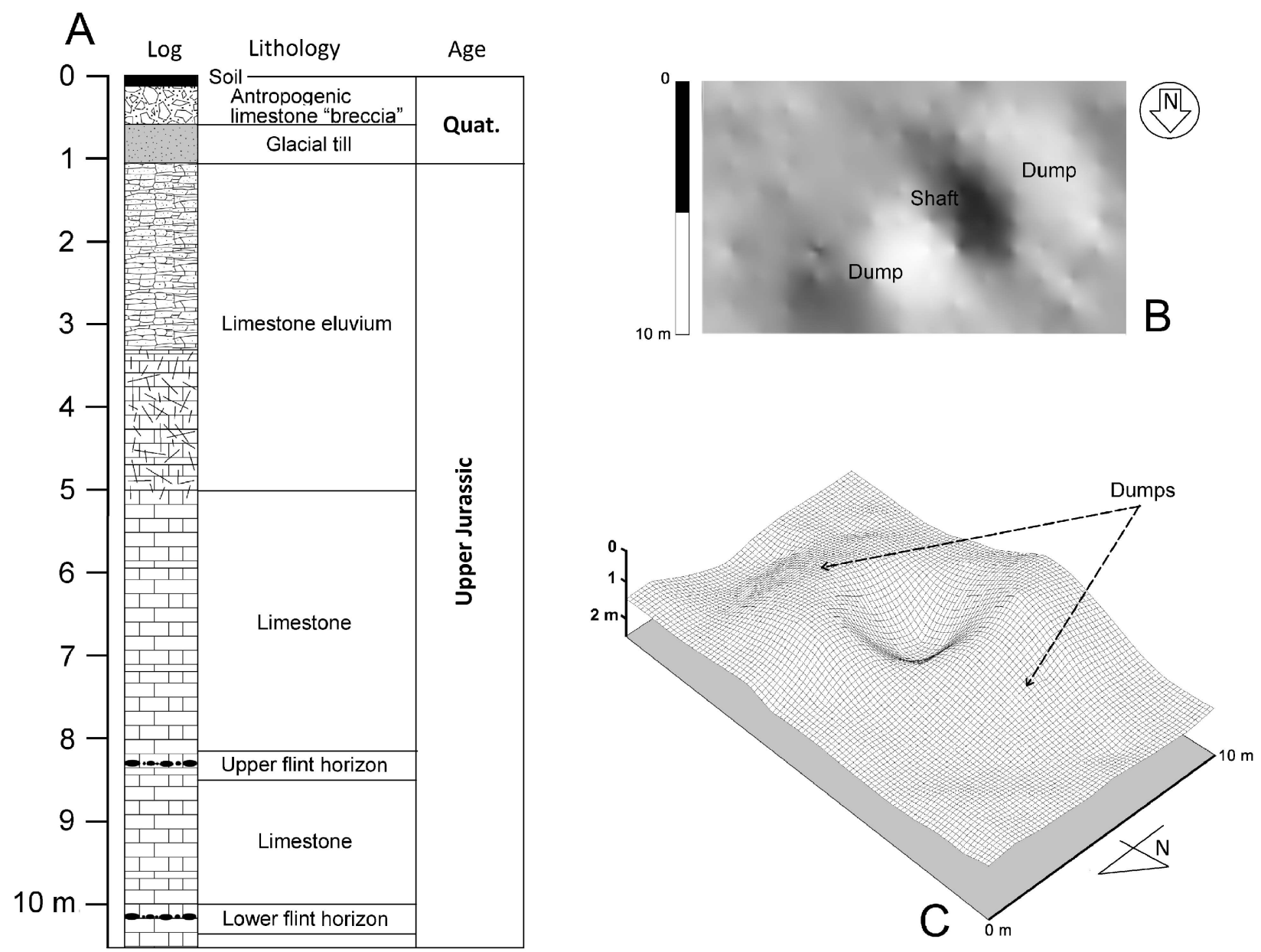

Fig. 4. Geological settings of the mine no. 612. A-Simplified lithological column for the shaft 612 . B, C-3D visualizations of a depression indicating a position of the shaft 612 and the surrounding debris (drawing by F. Welc).

back to the surface. Vertical shafts that are usually filled with limestone debris create areas of high amplitude point-source reflections from individual clasts of limestone and chert, which are readily visible in reflection profiles (Conyers, 2013). However, in case of the study area, the chert-bearing carbonate formation is overlain by a thick bed of soil and mining debris, which is high in clay, creating a variable environment that affected propagation of radar energy to depth.

The shaft 612, the main target of the survey, is located in a southern part of the segment A at the Krzemionki archaeological site (Fig. 1). It is marked by $0.50 \mathrm{~m}$ deep depression surrounded by small mounds still visible on a land surface, which points to location of the main exploitation shaft with two adjacent mounds of rock debris (about $0.60 \mathrm{~m}$ high), in the southwestern and northeastern parts of the feature (Fig. $3 \mathrm{~A}, \mathrm{~B})$. In the same area there is an underground tourist route dug near the shaft 612 that was used to calibrate depth axis on reflection profiles. Another deep tourist shaft and drilled boreholes made by the authors nearby allowed to established a stratigraphic sequence of the bedrock and near-surface sediments to be analysed (Table 1; Fig. 4A-C).

It is important to note, that drilling made inside the shaft 612 revealed its bimodal structure. The infilling was composed in the upper part of the shaft by strongly compacted limestone debris and in the lower part by a debris-sand con- glomerate of deluvial origin (slope wash), characterized by high contribution of clay and clay minerals.

GPR surveys were conducted both within a depression of the shaft 612 and the surrounding dumps of limestone debris. Several parallel reflection profiles were collected with both 500 and $250 \mathrm{MHz}$ antennas, with profiles spaced at 50 $\mathrm{cm}$ from one another. The $100 \mathrm{MHz}$ antennas were also used in the hope of visualizing deep features in this vertical shaft area with profiles spaced at $1 \mathrm{~m}$ from one another (Fig. 5).

\section{RESULTS OF GPR SURVEY}

The data obtained by using the antenna of $100 \mathrm{MHz}$ frequency are characterized by relatively low resolution but on the other hand, with considerable depth of energy penetration. In one of these profiles, collected over a middle part of the shaft 612 (Fig. 6), adjacent rubble dumps surrounding mouth of the shaft on both eastern and western sides are denoted. The shaft itself is filled with debris and produces a variety of distinctive reflections hyperbolas from larger clasts of limestone debris. A roof of the modern underground tourism walkway at a depth of approximately $7 \mathrm{~m}$ is visible as a high amplitude planar reflection generated from its roof(Fig. 6A). Despite a low-resolution of reflection profiles obtained using $100 \mathrm{MHz}$ antenna, the data re-processed in time slices 


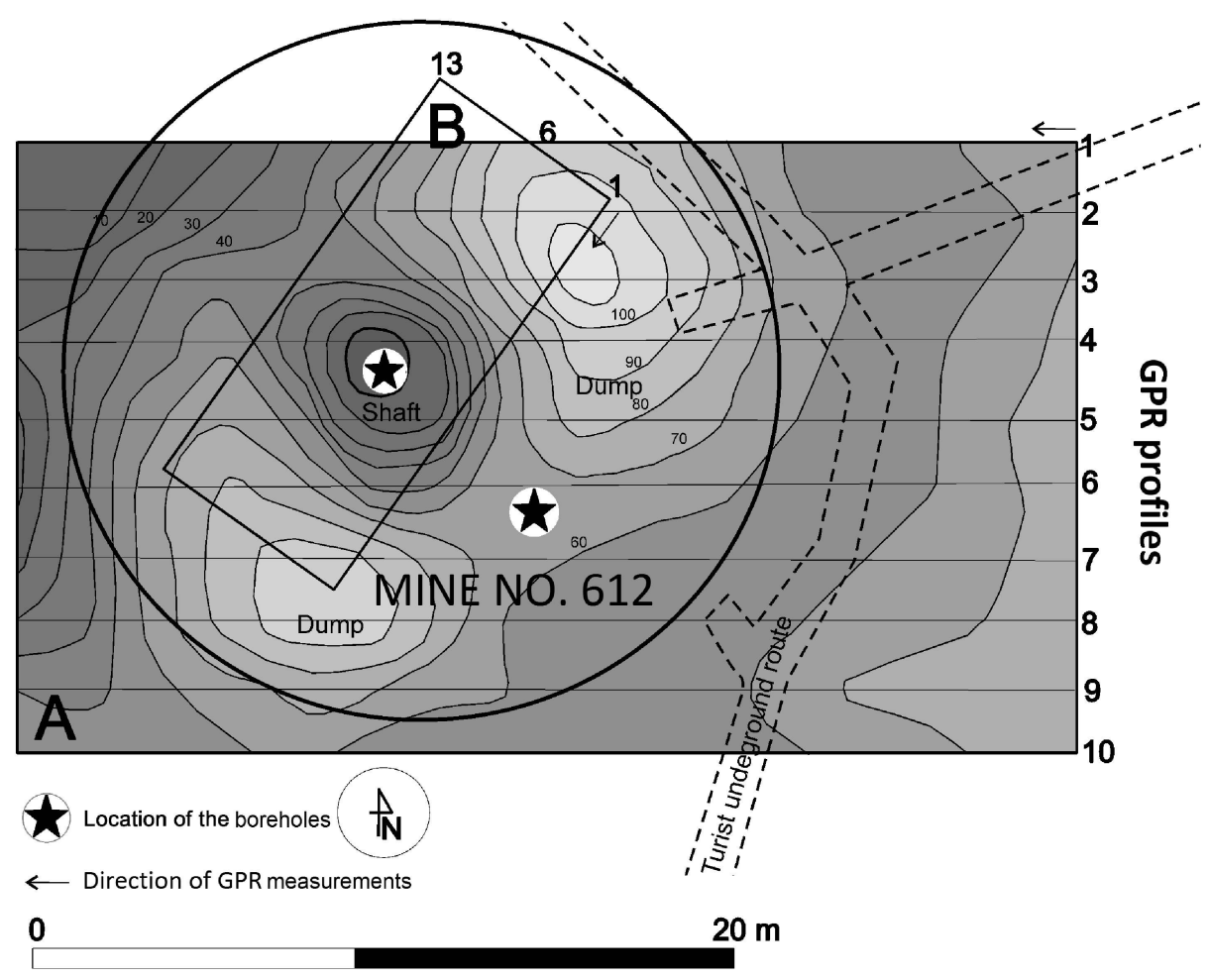

Fig. 5. Location of the study areas near the shaft 612 . A - for antenna $100 \mathrm{MHz}, \mathbf{B}$ - for antenna 500 and $250 \mathrm{MHz}$; drilling points are marked by stars.

reveal not only location of the main shaft but also extents of surrounding dumps to depth of $2 \mathrm{~m}$ (Fig. 6B).

For comparison, GPR data from the $500 \mathrm{MHz}$ antenna show maximum depth penetration of about $3 \mathrm{~m}$. In this case, reflection profiles reveal detailed structure of the upper part of shaft belonging to the mine 612. Especially well visible is a filling of the uppermost part of the shaft mouth revealing its collapse features which consist of packages of slope deposits and lose limestone rubble (Fig. 7). 3D block diagram and time slices reveal extension and structure of rubble dumps surrounding a shaft hollow (Fig. 8A, B). The hollow is clearly visible in amplitude maps as an area with few if any reflections in the upper levels and large rubble materials filling in a columnar feature with depth (Fig. 8B).

The $250 \mathrm{MHz}$ reflection profiles, after correcting for topography, reveal detailed stratigraphy within limestone units at a much greater depth (Fig. 9). High amplitude planar reflection just below the surface was generated at contact of surface soil and subsoil layer about $20 \mathrm{~cm}$ thick. Below this, there was a second unit about $1 \mathrm{~m}$ thick locally where only low amplitude reflections were recorded, corresponding to residuum of glacial tills (Fig 9: profile 1). At about $3 \mathrm{~m}$ depth there is another distinct reflection boundary, which corresponds to a lithological boundary between the Quaternary and the weathered and fractured top of a pelitic limestone massif (see Fig. 4). Worth noting is a depression in the western part of the profile 1 , which is most probably a shallow vertical shaft that may be an earlier excavation feature. A concentration of reflection features is visible between 16 and $23 \mathrm{~m}$ in the western part of the profile 5 (Fig. 9). These reflections are a result of debris in the upper part of the shaft with a diameter of about $4 \mathrm{~m}$. A series of high-amplitude re-

General stratigraphy of the study area

\begin{tabular}{|c|l|c|}
\hline Depth & \multicolumn{1}{|c|}{ Lithology } & Age \\
\hline $0.0-0.6 \mathrm{~m}$ & Soil underlain by a debris embankment, formed of small fragments of weathered limestone with a silty-sandy matrix & \multirow{2}{*}{ Quaternary } \\
\hline $0.6-0.8 \mathrm{~m}$ & Glacial till and glaciofluvial sand and clay contents & \\
\hline $0.8-3.28 \mathrm{~m}$ & Unconsolidated limestone debris with clay matrix & Upper \\
\hline $3.28-5.0 \mathrm{~m}$ & Pelitic limestone (fractured), passing into limestone debris in the top, with a layer of coral limestone (fractured) below \\
\hline $5.0-8.3 \mathrm{~m}$ & Layer of monolithic oolite limestone, forming a roof of most mine excavations in the segment A \\
\hline $8.3-8.4 \mathrm{~m}$ & Layer of white pelitic limestone with a detached upper horizon of striped flint \\
\hline $8.4-10.2 \mathrm{~m}$ & Layer of white pelitic limestone & \\
\hline $10.2-10.3 \mathrm{~m}$ & Horizon of striped flint in form of flat nodules & \\
\hline $10.3-10.7 \mathrm{~m}$ & Layer of white pelitic limestones; both flint horizons (upper and lower) dip at about $4^{\circ}$ to the east \\
\hline
\end{tabular}




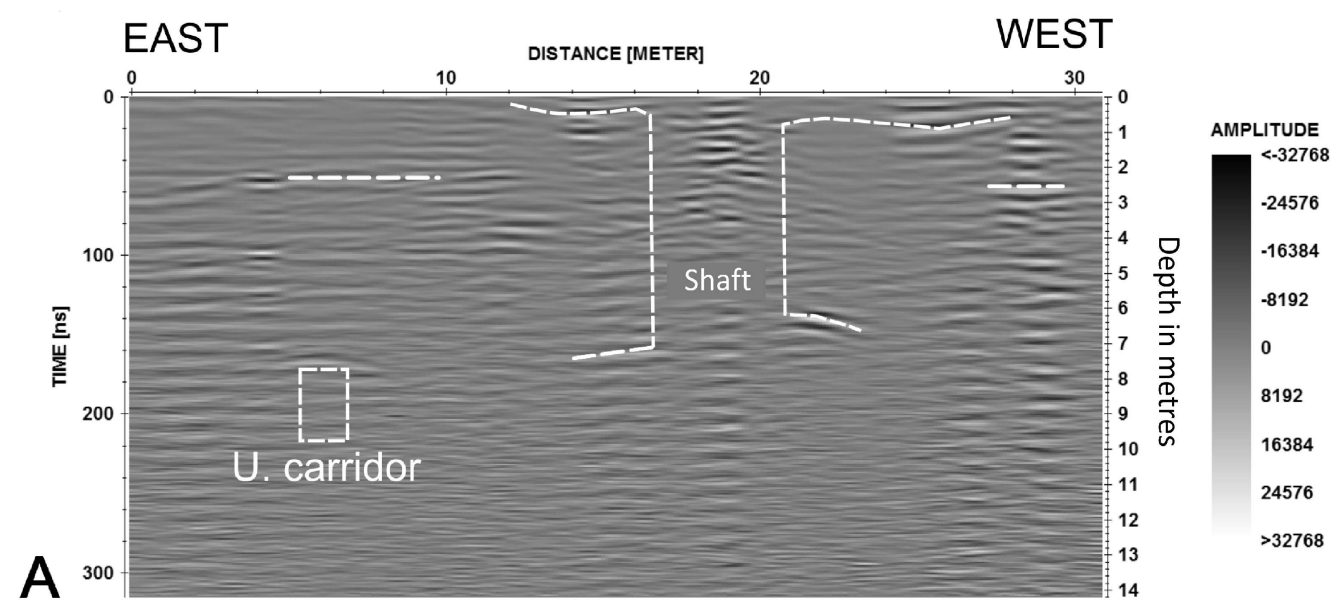

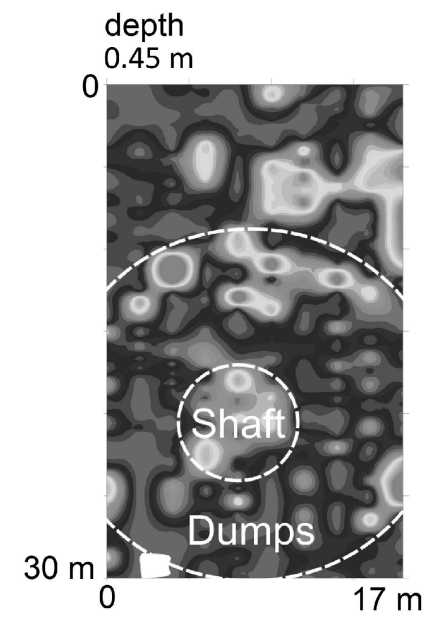

$1.80 \mathrm{~m}$
$0.90 \mathrm{~m}$

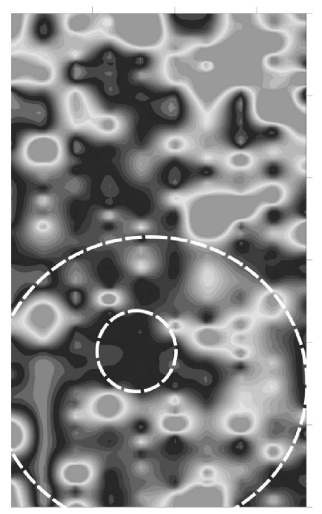

$2.25 \mathrm{~m}$
$1.35 \mathrm{~m}$

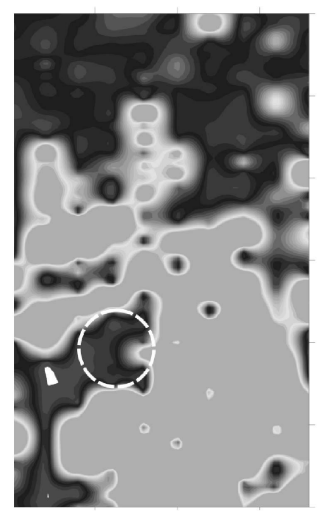

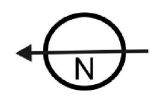

0
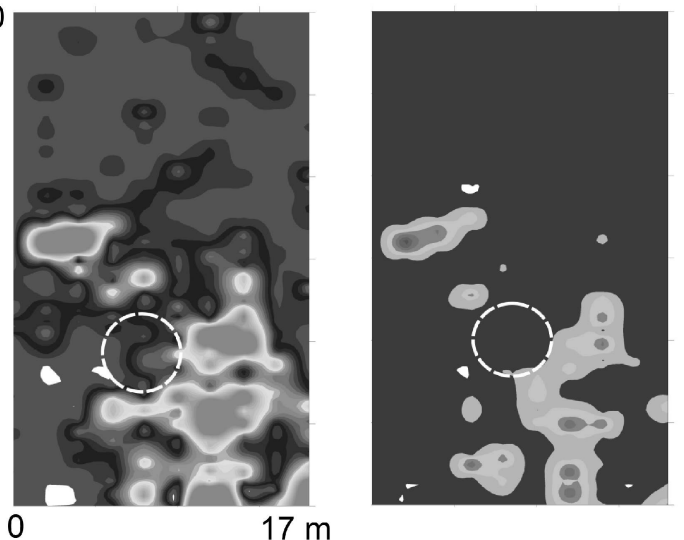

B $30 \mathrm{~m}$

$17 \mathrm{~m}$

Fig. 6. Results of the survey around the shaft 612 using antenna $100 \mathrm{MHz}$ (without topographic correction). A-selected reflection profile with visible echo of the mine shaft (outlined) surrounding dumps and location of an underground corridor indicated by reflection hyperbolas; note a relatively low resolution of the image. B - horizontal slices at selected depths revealed outline of the dumps of limestone debris surrounding the shaft well.

flections directly above the shaft were produced from limestone debris filling a synclinal depression at the shaft mouth. The 3D block diagram of a portion of the shaft 612 between $3 \mathrm{~m}$ and $6 \mathrm{~m}$, obtained with a use of $500 \mathrm{MHz}$ reflection profiles constructed with 3D mode based on ReflexW, shows this debris fill of the shaft and other reflections from bedding surfaces in the limestone bedrock (Fig. 10).
A detailed analysis of the $70 \mathrm{~m}$ long GPR refection profile (see location on Figs 3A, 11) allows describing an underground structure of the shaft 612 and adjacent mine shafts. The profile contains also a number of very important details concerning geological structure of the area in question. Between 0 and 20 ns (Fig. 11), velocity analysis used by hyperbola fitting shows values used by consistent with a subsurface 


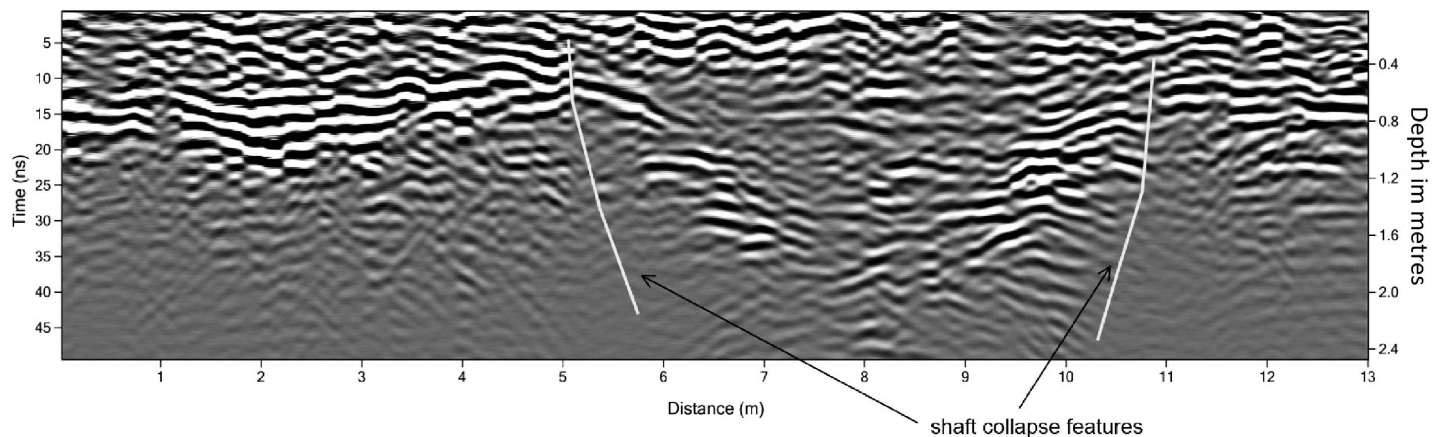

Fig. 7. Reflection profile showing the uppermost part of the shaft 612 . Shaft collapse features are very well visible.

Table 2

Main GPR facies and their interpretation

\begin{tabular}{|l|l|}
\hline \multicolumn{1}{|c|}{ GPR facies } & \multicolumn{1}{c|}{ Interpretation } \\
\hline Reflection free zones & $\begin{array}{l}\text { Areas where GPR energy is attenuated, usually by layers of clay or sands with clay content; however, al- } \\
\text { though clay minerals play an important role in radar energy attenuation, its real mechanism is still poorly } \\
\text { understood (see Conyers, 2013) }\end{array}$ \\
\hline $\begin{array}{l}\text { Reflection hyperboles (so called point } \\
\text { source reflections) }\end{array}$ & $\begin{array}{l}\text { Characteristic reflection hyperbolas of different shape and size, generated by underground features such as } \\
\text { stone fragments, callings of the underground galleries or metal objects }\end{array}$ \\
\hline $\begin{array}{l}\text { Discontinuous and zones of wave diffrac- } \\
\text { tions }\end{array}$ & Mostly generated by poorly bedded limestone debris and concentration of small objects \\
\hline Reflection planar surfaces & Usually generated by lithological boundaries or some physical discontinuities (e.g. water table) \\
\hline Layered and parallel reflections & $\begin{array}{l}\text { So-called multiple reflections (multiples) are generated when radar energy reflects back and forth between } \\
\text { buried object and ground surface; in other causes the radar energy is traveling forward and back between } \\
\text { lithological boundaries (see Conyers, 2013) }\end{array}$ \\
\hline
\end{tabular}

layer composed of clay and sands. Between 20 and $40 \mathrm{~ns}$, a zone of strong attenuation of electromagnetic waves is well visible (Fig. 11). Below $40 \mathrm{~ns}$ radar wave velocity increases again and reaches $0.08-0.09 \mathrm{~m} / \mathrm{ns}$, which corresponds to sands and limestones with smaller clay content. At approximately 65 ns characteristic large diffraction hyperbolas are visible and radar wave propagation in the medium is just 0.30 $\mathrm{m} / \mathrm{ns}$, different insignificantly from the overlying layers. At this depth radar energy is essentially moving in the air, with velocities consistent with the light speed, what indicates that these hiperbolas are produced probably by trees branches or an electric line located within the area of GPR survey. Below $80 \mathrm{~ns}$, a mean wave velocity in the medium is $0.08-0.09$ $\mathrm{m} / \mathrm{ns}$, indicating a top of local limestone bedrock. Below $100 \mathrm{~ns}$ a velocity of wave propagation changes slightly, from 0.06 to $0.09 \mathrm{~m} / \mathrm{ns}$ only.

A reason of strong attenuation of the GPR signal below $4.5 \mathrm{~m}$, i.e. the depth below a lower part of the shaft 612 is very poorly visible on reflection profiles, remains complex. The drillings have clearly shown that the upper part of the shaft is filled with silty sands and limestone debris (from the surrounding debris dumps), generating high-amplitude anomalies and sets of diffraction hyperboles. Below a depth of $4 \mathrm{~m}$ the shaft is filled with deluvial sediments, which contain significant contribution of clay minerals. Such significant lithological contrast reflects precisely a structure of the upper debris layers and their lower boundary with underlying deluvial sequences, which by their different mineral composition strongly attenuate electromagnetic waves, significantly re- stricting the depth range of GPR survey. Presence of clay and clay minerals within sediments infilling the well should be considered as the main reason of strong attenuation of electromagnetic waves, additionally influencing reduction of a depth of the GPR prospection.

The undulating planar reflection marking a ceiling of the tourist tunnel is measured at $7.8 \mathrm{~m}$ using the velocities measured by a hyperbola fitting (Fig. 11C), which corresponds to actual depth of this structure according to building documentation. In addition, a polarity of reflected waves generated at a boundary of the ceiling within a tunnel void space was studied to confirm that it was the tunnel in fact. Because radar waves moving into a void will reflect energy back to the surface with reversed polarity (Conyers, 2013). A selected trace was used to display this reversed polarity (Fig. 11C). This kind of wave polarity analysis can also be used as an aid in interpretation, especially to confirm reflections from void spaces as well as the underground tunnels. Due to a diffraction hyperbole marking a top of the underground tourist route, the depth axis (y) was calibrated accordingly and the average velocity of electromagnetic wave propagation was assumed for the analysed geological medium at $0.09 \mathrm{~m} / \mathrm{ns}$. This enabled precise determination of a depth of all mining structures discovered at reflection profiles.

GPR facial analysis of reflection profiles is especially important when working in complex buried structures and various features are visible and unique to certain stratigraphic context. These features are listed (Table 2) with general analysis of reflection continuity, shape, amplitude, inter- 


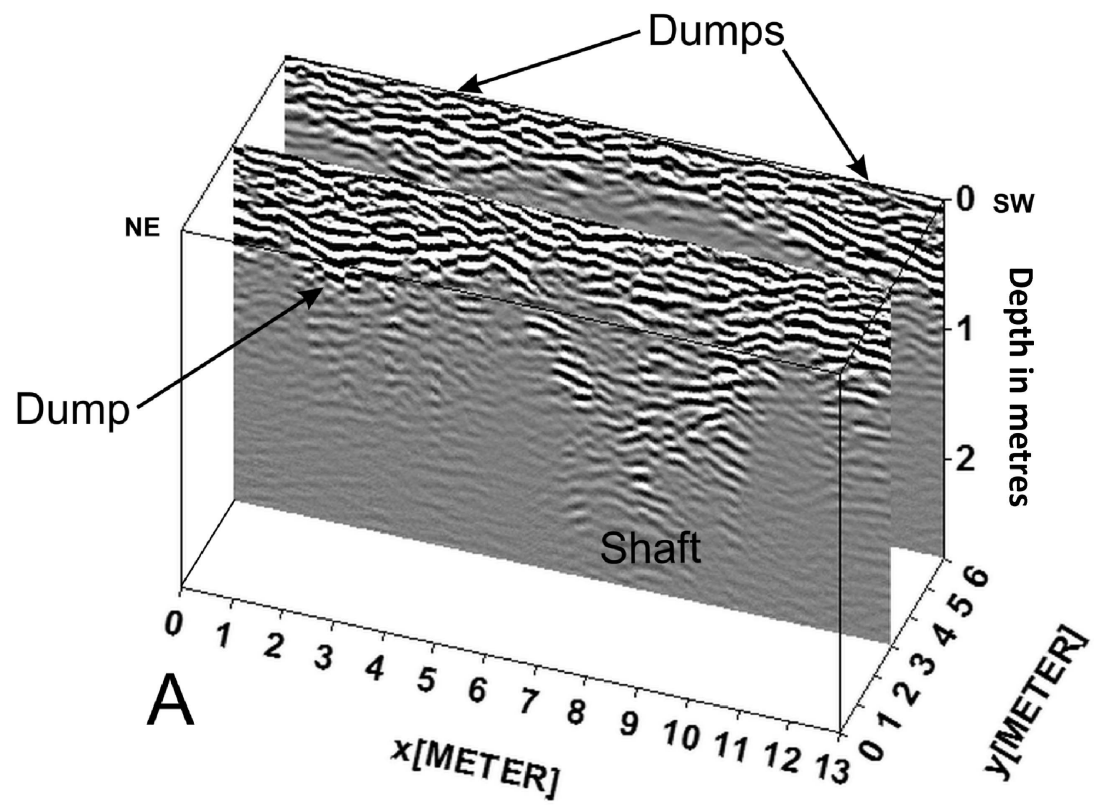

\section{Amplitude \\ $<-1166$ \\ $-875$ \\ $-583$ \\ $-292$ \\ 0 \\ 292 \\ 583 \\ 875 \\ $>1166$}

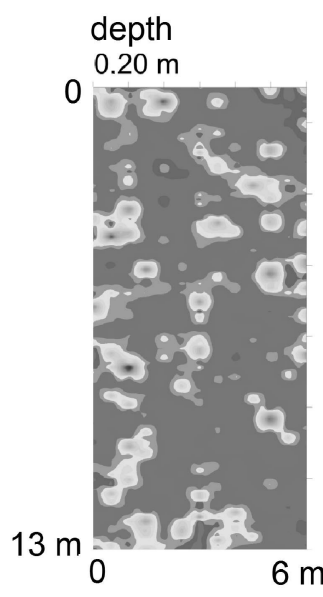

$0.40 \mathrm{~m}$

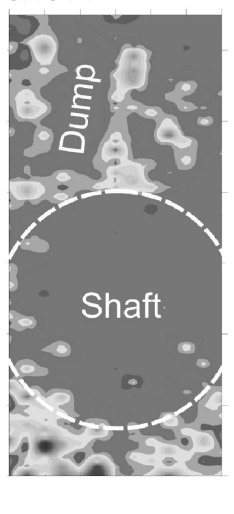

$0.80 \mathrm{~m}$

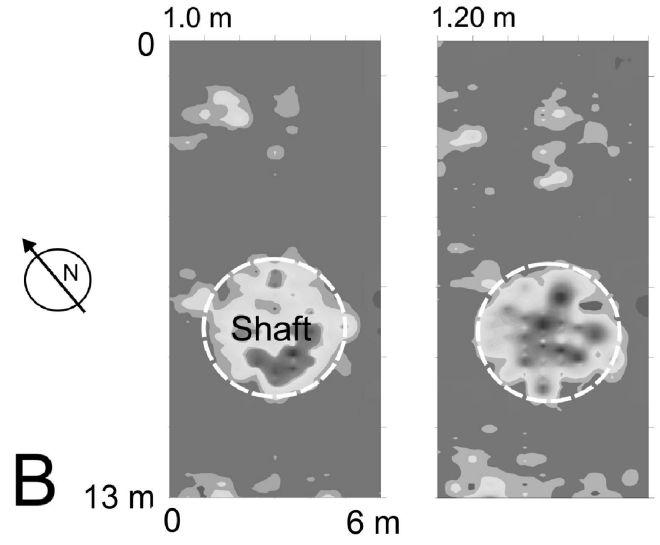

Fig. 8. Results of the survey around the shaft 612 using the antenna $500 \mathrm{MHz}$ (without topographic correction). A-3D compilation of selected reflection profiles with location of debris dumps and mine shaft. B - Time slices at selected depths with dumps of limestone debris and shaft well.

nal reflection configuration and external form using GPR facial approach applied by Beres and Haeni (1991), Beres et al. (1999) and Ekes and Hickin (2001).

Variety of anthropogenic structures and natural bedrock units are distinctly visible on the analysed reflection profile.
These are summarized on Fig. 12 with interpretation on Table 2. They included areas where GPR energy was attenuated, usually by layers of clay or sands with clay content. Other two GPR facial group were composed of characteristic reflection hyperbolas generated by underground anthropo- 

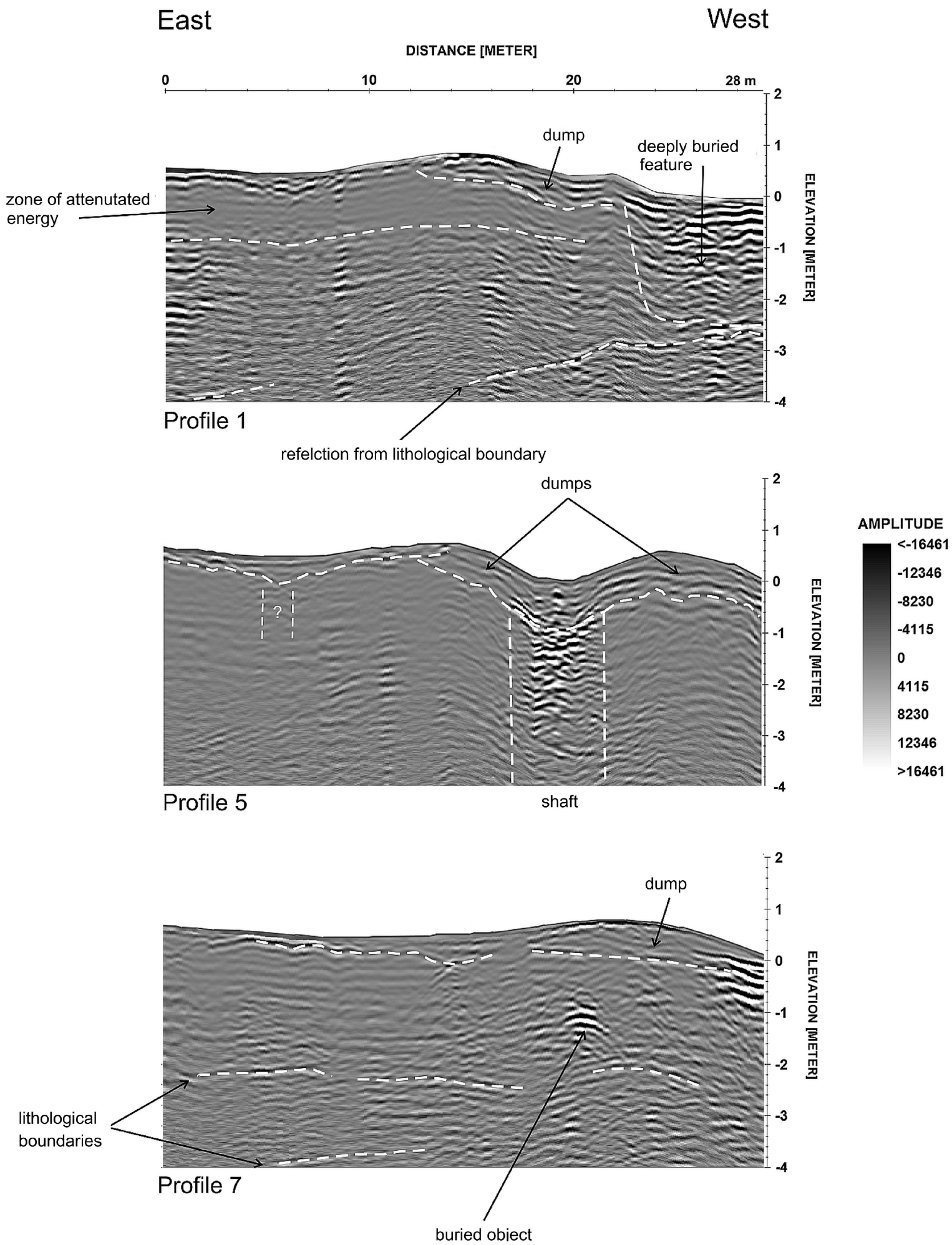

Fig. 9. Selected three reflection profiles made using the antenna $250 \mathrm{MHz}$ with interpretation.

genic features and distinct reflection produced by lithological boundaries. The so-called multiple reflections (multiples) consisted the last group.

An interpretation of reflection profiles and 3D block diagrams obtained during GPR surveys of the shaft 612 at Krzemionki allows interpreting a set of anomalies as an image generated by a chamber mine, belonging to the most ad- vanced engineering objects at the Krzemionki Opatowskie mining field. Shafts of this type reached depth of about $9 \mathrm{~m}$. The exploitation galleries attained distance of over $20 \mathrm{~m}$ from the shaft axis. In some cases, surfaces of the underground excavations are estimated at several hundred square metres. This assumption is confirmed by height and structure of two debris dumps surrounding the shaft well. Mines lo- 


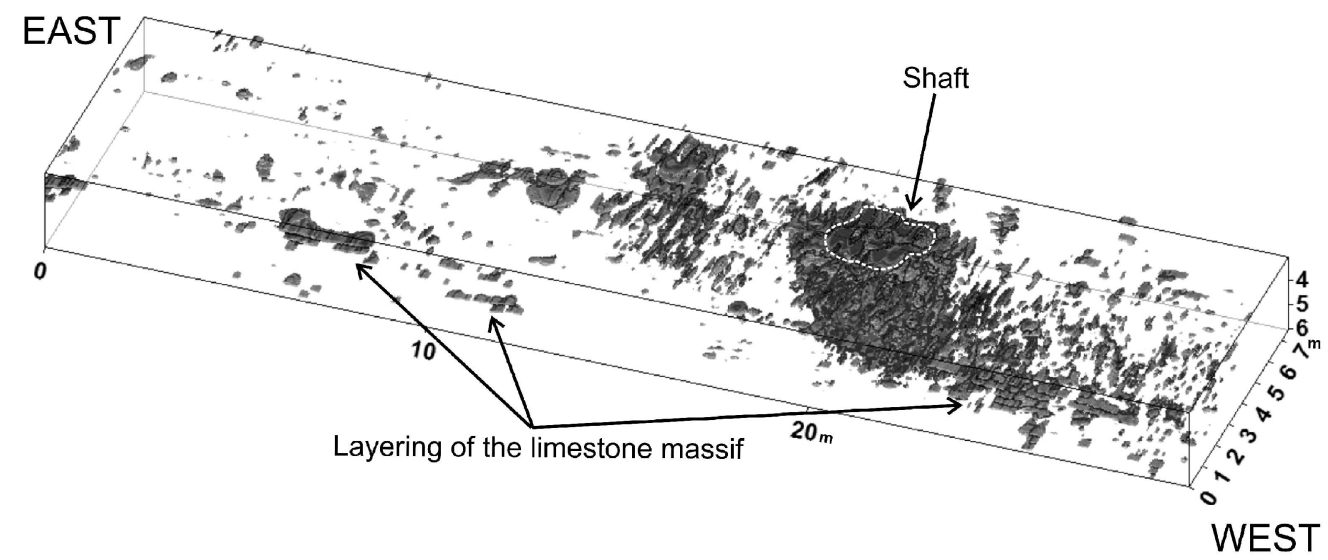

Fig. 10. Quasi-3D image of the shaft 612 at depth 3-6 m; note bedding of the limestone massif, with dip towards the east.

cated to the west from the shaft 612 are shallower but they have a more complex system of underground excavations. Concentration and pattern of diffraction hyperboles suggests that two flint horizons were exploited in these excavations, which were pillar-chamber mines.

\section{CONCLUSIONS}

Prehistoric flint mines are characterized by an extremely complex underground structure and they are therefore very difficult to examine by geophysical methods. Since 2014 the area of a vast prehistoric flint mine at Krzemionki Opatowskie (central Poland) was surveyed using the ground-penetrating radar. One of the goals of this project was to map the underground tunnels and vertical shafts and test hypotheses regarding orientation, depth and complexity of these structures. The survey was concentrated around the shaft 612 located in a southern part of the segment A of the Krzemionki mining field, where deepest underground structures are preserved.

During the survey the Mala GPR radar system was used equipped with 250,500 and $100 \mathrm{MHz}$ antennas respectively. All obtained reflection profiles were processed using ReflexW and GPR Process and GPR slices software. Processing procedures such as running average background removal filters, Dewow, DC - shift adjustments, AEG gain and manual gain adjustments and various band-pass frequency filtering were applied. In case of some profiles, additionally deconvolution, F-k filtration and migration processing was applied as well. To create amplitude maps (slices) the GPR Process software was used.

Conducted GPR survey have evidenced GPR usability in investigations of prehistoric mining fields, particularly with application of antennas 100, 250 and $500 \mathrm{MHz}$. Reflection profiles obtained by the using of antenna of $100 \mathrm{MHz}$ are characterized by relatively low resolution but deep range of vertical prospecting. Despite a low resolution these profiles revealed interesting archaeological features to depth of nearly $9 \mathrm{~m}$. In contrast, GPR profiles from the $500 \mathrm{MHz}$ antenna are much more detailed in archaeological features but the depth of prospecting does not exceed $3 \mathrm{~m}$, mostly due to specific local geological structure. The most successive results were achieved by using $250 \mathrm{MHz}$ antenna. Due to dif- fraction hyperbole marking a top of the underground tourist route, a depth axis (y) was calibrated accordingly and an average velocity of electromagnetic wave propagation was assumed for the analysed geological medium at $0.09 \mathrm{~m} / \mathrm{ns}$. This enabled precise determination of the depth of mining structures discovered on reflection profiles.

Analysed reflection profiles revealed a great number of archaeological and geological features, especially after topography correcting. Using two-dimensional reflection profiles and 3D block diagrams, vertical shafts filled mostly with lithic debris were easily traced and mapped. From the other hand, time slices prepared for selected depths could visualize debris (dumps) on margins of the shafts as well as collapsed material that fills the voids. Some of shallower horizontal tunnels were also visible as sub-horizontal planar reflections generated from both ceiling and floors of these void spaces. A detailed analysis of the GPR $70 \mathrm{~m}$ long reflection profile allowed describing an underground structure of the mine 612 and adjacent mine shafts and distinguished main GPR facies (specific groups of GPR anomalies). Velocity analysis used by hyperbola fitting based on this profile was also very useful to recognize a geological structure of the area of the shaft 612.

Geological setting of the study area, including a Quaternary cover rich in clay was a strong obstacle. Despite that, obtained results have allowed to determine not only the depths of recognized mining structures but also their structural-engineering characteristics. These results allowed concluding that application of appropriate antennas and proper network of profiles will create 3D underground structures of the mining field at Krzemionki in the future.

Summing up, detailed analysis of GPR reflection profiles and amplitude maps allow identifying a number of important anthropogenic features in ancient mining district at Krzemionki including vertical shafts, horizontal tunnels, debris infilling of these hollow features and surface debris associated with mining. Vertical shafts are the most readily discoverable as their truncation surfaces against the bedrock are easily identified by contrast in reflection types. Horizontal tunnels are a little more challenging as they can be confused with horizontal or sub-horizontal bedding planes in the bedrock. The two can be differentiated by analysing polarity 

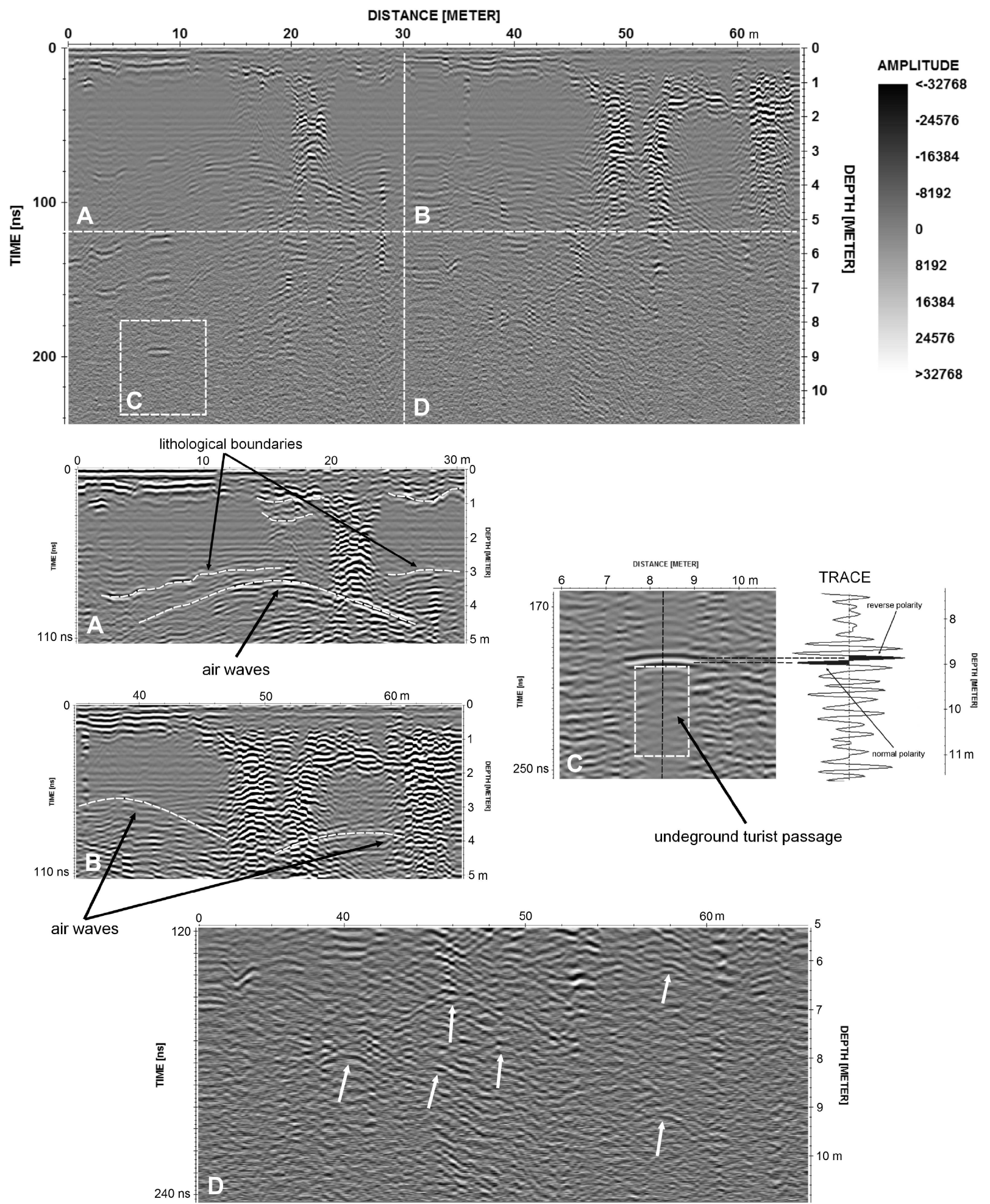

Fig. 11. Reflection profile, $66 \mathrm{~m}$ long, showing the shaft 612 and geological structure of the area (see detailed description in text).

differences in reflection traces, with a reverse polarity reflection generated from interface between a void space and an overlying bedrock (Conyers, 2013). Extension of these interpretation to un-mapped areas of ancient mining districts will determine excavation intensity and exploitation techniques used during the Neolithic in the prehistoric mining features.

\section{Acknowledgements}

The authors wish to thank the Archaeological Museum and Reserve „Krzemionki” for the opportunity to perform GPR research in the area of the shaft 612 . 

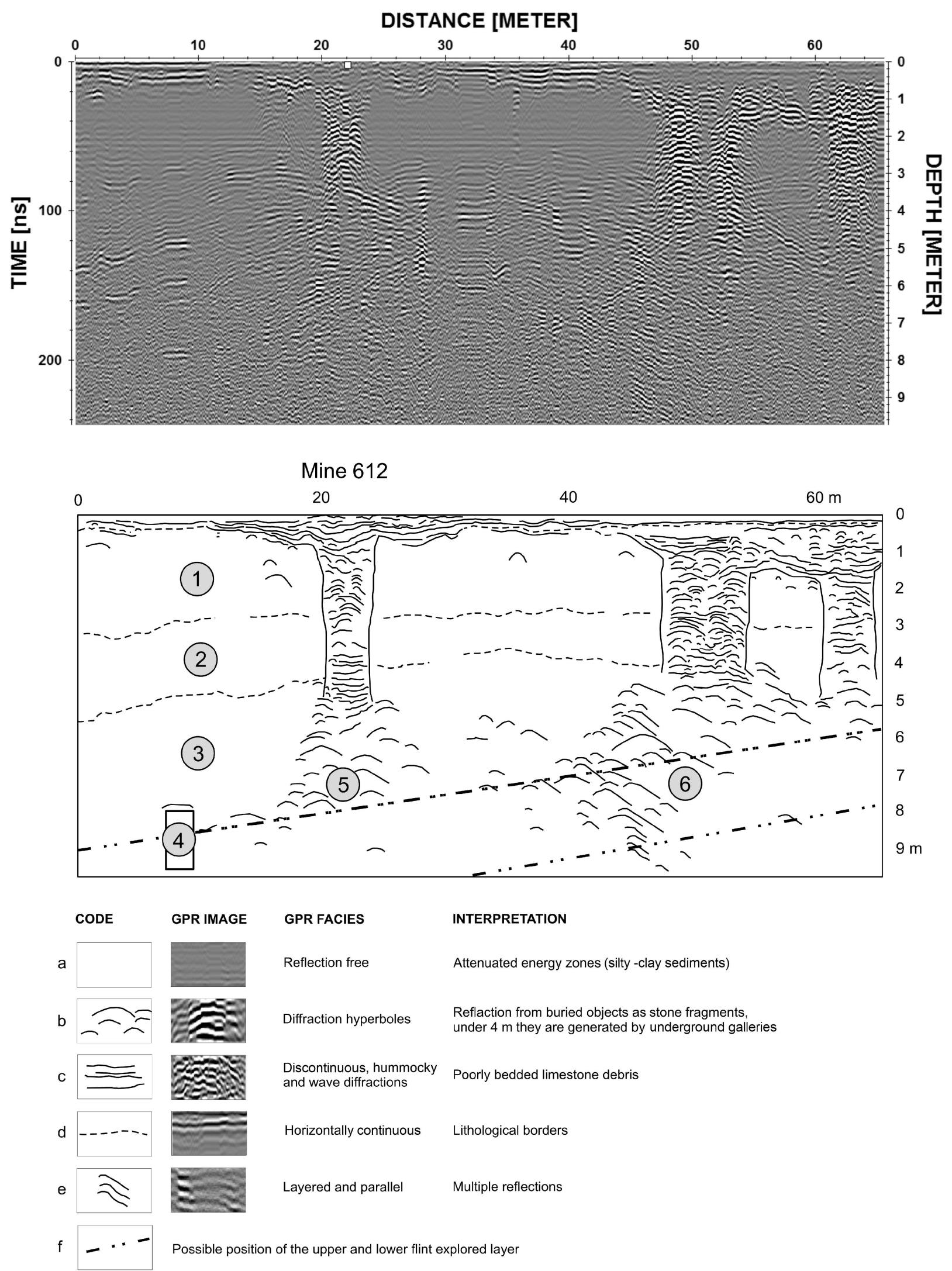

Fig. 12. Reflection profile with the shaft 612 and subsequent mining excavations in the west, including a hypothetical course of the flint horizons. 1 - sand, loam, limestone debris (zone of electromagnetic wave attenuation), 2 -topmost, weathered part of a limestone formation, 3 - monolithic massif, 4 - tourist underground passage, 5 - concentration of numerous diffraction hyperboles, generated by excavation of the shaft 612,6 - concentration of diffraction hyperboles generated by the neighbouring mines. 


\section{REFERENCES}

Babel, J., 1986. The problem of investigations of the flint mine at Krzemionki near Ostrowiec Świętokrzyski, Kielce and Tarnobrzeg voivodeships. International conference on prehistoric flint mining and raw material identification in the Carpathian Basin, Budapest - Sümeg, May 20-22, 27-42.

Bąbel, J., 2008. Krzemionki Opatowskie. The earliest beginnings of modern mining. In: Wiśniewski, L. (Ed.), New Challenges and Visions for Mining 21st World Mining Congress. The mine as witness to history and a monument of technology. Abstracts of Papers, 87-109.

Bąbel J., 2015. Krzemionki Opatowskie". Monument prahistorii Europy. Kopalnie krzemienia pasiastego (Monument of the prehistory of Europe. The striped flint mines). Ostrowiec Świętokrzyski: Muzeum Historyczno-Archeologiczne.

Beres, M., Haeni, F.P., 1991. Application of the ground-penetrating radar methods in hydrogeologic studies. Groundwater 29 (3), 375-386.

Beres, M., Huggenberger, P., Green, A.G., Horstmeyer, H.H., 1999. Using two and three-dimensional georadar methods to characterize glaciofluvial architecture. Sedimentary Geology $129,1-24$.

Beres, M., Luetscher, M., Olivier, R., 2001. Integration of groundpenetrating radar and microgravimetric methods to map shallow caves. Journal of Applied Geophysics 46, 249-262.

Borkowski, W., 1990a. Preliminary results of geophysical studies by the subsurface interface radar system of the Krzemionki banded flint mining field. Materiały Krzmionkowskie, 118 136.

Borkowski, W., 1990b. Results of subsurface radar Ggophysical studies of Krzemionki banded flint mines, Poland. In: Pernicka, E., Wagner, G. (Eds.) Archeometry 90. Basel, 687-696.

Borkowski, W., 1995a. Krzemionki mining complex. Deposits managment system. Studia nad gospodarką surowcami krzemiennymi w pradziejach 2 . Warsaw.

Borkowski, W., 1995b. Prehistoric flint mines complex in Krzemionki (Kielce Province). Archaeologia Polona 33, 506-524.

Borkowski, W., 2000. Zastosowanie metod radarowej i sejsmicznej w lokalizacji podziemnych wyrobisk górniczych na podstawie wyników prac prowadzonych w Krzemionkach Opatowskich (The use of radar and seismic methods in the location of underground mining structures based on the results of work carried out in Krzemionki Opatowskie). In: Borkowski, W. (Ed.) Metody badań archeologicznych stanowisk produkcyjnych górnictwo krzemienia. Warszawa, 238-257.

Borkowski, W., Michniak, R., 1992. Prehistoryczne pole eksploatacyjne (wybierkowe) w Krzemionkach (Prehistoric exploatation in Krzemionki). Materiały Krzemionkowskie 1, 11-36.

Boubaki, N., Saintenoy, A., Kowalczyk, S., Mieszkowski, R., Welc, F., Budziszewski, J., Tucholka, P., 2012. Ground-penetrating radar prospection over a gallery network resulting from Neolithic flint mine (Borownia, Poland). In: Proceedings of the 14th International Conference on Ground Penetrating Radar (GPR), June 4-8, Shanghai, 610-615.

Chamberlain, A. 2000. Cave detection in limestone using ground penetrating radar. Journal of Archaeological Science 27, $957-$ 964.

Collins, M. E., Cum, M., Hanninen, P. 1994. Using ground penetrating radar to investigate a subsurface karst landscape in North-Central Florida. Geoderma 61, 1-15.
Conyers, B.L., 2013. Ground-penetrating radar for archaeology. 3rd Ed. Altamira Press.

Conyers, B.L., 2016. Ground-penetrating radar for geoarchaeology. Wiley Blackwell.

Conyers, B.L., Goodman, D., 2007. Ground penetrating radar. Aracne, Roma.

Ekes, C., Hickin., E.J., 2001. Ground penetrating radar facies of the paraglacia Cheekye Fan, southwestern British Columbia, Canada. Sedimentary Geology 143, 199-217.

El-Quady, G., Hafez, M., Abdalla, M. A., Ushijima, K., 2005. Imaging subsurface cavities using geoelectric tomography and ground-penetrating radar. Journal of Cave and Karst Studies 67 (3), 174-181.

Galiberti, A., Salvini, R., Tarantini, M., Mantovani, F., Bottacchi, M., Callegari, I., Lino, M., Matteo, F., Claudio, R., Massimiliano, 2011. Mining landscape and mines. Integrating digital aerial photogrametry and Geophysical prospecting in Gargano area (Italy). In van Leusen, M., Pizziolo, G., Sarti, L. (Eds.), Hidden Landscapes of Mediterranean Europe Cultural and methodological biases in pre- and protohistoric landscape studies Proceedings of the international meeting Siena, Italy, May 25-27. BAR International Series, 23-20.

Goodman, D., 1994. Ground-Penetrating Radar Simulation in Engineering and Archaeology. Geophysics 59, 224-232.

Imai, T., Sakayama, T., Kanemori, T., 1987. Use of Ground-Probing Radar and Resistivity Surveys for Archaeological Investigations. Geophysics 52, 137-150.

Koch, J., Fassbinder, J.W.E., Linck, R., Eisele, K., Rind, M.M., 2013. The Neolithic flint mine of Arnhofen in Lower Bavaria, southern Germany: Aerial Archaeology, magnetometry and Ground - penetrating radar surveys. Archaeological Prospection. Proceedings of the 10th International Conference, Vienna, May 29 - June 2.

Leopold, M., Völkel, J., 2005. Neolithic int-mines in Arnhofen, Southern Germany: a ground penetrating radar survey as a planing tool for archaeological excavation. Geophysical Research Abstracts 7, 06441, DOI: 1607-7962/gra/EGU05A-06441.

Leucci, G., De Giorgi, L. 2005. Integrated geophysical surveys to assess the structural conditions of a karstic cave of archaeological importance Natural Hazards and Earth System Sciences 5, $17-22$.

Mieszkowski, R., Welc, F., Budziszewski, J., Migal, W., Bakowska, A., 2014. Preliminary results of the Ground penetrating radar (GPR) prospection in the area of the Prehistoric Flint mine Borownia, southeastern Poland. Studia Quaternaria 31(2), 123-132.

Vaughan, C. J., 1986. Ground-penetrating radar surveys used in archaeological investigations. Geophysics 51(3), 595-604.

Welc, F. Mieszkowski, R., Budziszewski, J., Wysocki, J., Kowalczyk, S., Nalazek, C., 2013. Przydatność metody georadarowej (GPR) w nieinwazyjnej prospekcji archeologicznej na przykładzie trzech typów stanowisk z obszaru Polski (The usefulness of ground-penetrating radar (GPR) method in non - invasive archaeological prospection of the selected three types sites from the area of Poland). Fontes Archaeologici Posnaniensis 50/2, 141-161.

Zhao, W., Forte, E., Levi, S.T., Pipan, M., Tian, T. 2015. Improved high-resolution GPR imaging and characterization of prehistoric archaeological features by means of attribute analysis. Journal of Archaeological Science 54, 77-85. 